\title{
Editor's Introduction: Reevaluating the Traditional Confucian Division between Mencius and Xunzi
}

\author{
Zou Xiaodong 鄒曉東 \\ Associate Professor of Philosophy, Advanced Institute for Confucian Studies, \\ Shandong University, Jinan, China \\ wanerniba@aliyun.com
}

Mencius [Mengzi 孟子, c. 372-289 BCE] held the view that human nature is good [xing shan 性善] whereas Xunzi 荀子 [с. 313-238 вСЕ] believed that human nature is bad [xing $e$ 性惡]. This is clearly recorded and elaborated in the two pre-Qin Confucian classics, the Mencius and the Xunzi. Mencius lived slightly earlier than Xunzi, and by the time Xunzi began expounding and transcribing his views, Mencius had probably passed away. However, Mencius and his theory that human nature is good had already become widely influential, and therefore, in advocating the theory that human nature is bad, Xunzi and his followers targeted their criticism at Mencius and his theory.

The eminent Confucian Dong Zhongshu 董仲舒 [179-104 BCE], who a few generations later helped establish the Han dynasty [2O2 BCE-22O] ideology, followed the Xunzi's arguments in criticizing the theory that human nature is good. Dong wrote, "To say that human nature is inherently good is equivalent to claiming that there is no need for people to receive education, that they must merely follow what comes naturally [ziran 自然] to them, even where that means contravening social order." ${ }^{1}$ Xunzi and Dong's arguments deeply influenced other Confucians, which led to a general emphasis on Xunzi and relative disinterest in Mencius from the Han to Tang [618-907] dynasties. Their line of argument can be summed up in a single sentence: If human nature is good, what is the need for instruction and learning?

Confucians in the Song [96o-1279] and Ming [1368-1644] eras pivoted away from that outlook. Even before the Mencian renaissance in the late Tang and

1 Dong Zhongshu 董仲舒, “Shi xing 實性 [The Actuality of Human Nature]," in Chunqiu fanlu yizheng 春秋繁露義證 [The Correct Meaning of the Luxuriant Dew of the Spring and Autumn Annals], annot. Su Yu 蘇輿, ed. Zhong Zhe 鐘哲 (Beijing: Zhonghua shuyu, 1992), 311. 
early Song, Chinese Buddhists had already begun a long and fruitful discussion of whether and to what extent humans possess a "Buddha nature." They ultimately landed on the Chan [zen] Buddhist ideas of "one's nature being originally pure," "one's nature being fundamentally eternal," "one's nature being originally perfect," "the original state of one's nature being without change," and "one's nature having the capacity to generate all things." The Chan view is a product of extended theoretical debate and analysis in the actual practice of Chinese Buddhism. Its basic logic is as follows: if practitioners do not already possess a "Buddha nature" ("pure nature" [qingjing zhixing 清淨之性], with a "self-so nature" [ziran zhi xing 自然之性]) to serve as a basis for their cultivation, then no matter how salutary their external conditions, they will be unable to fully realize the realm of Buddhahood through their self-cultivation.

The Song Confucians, who aspired to revive the proper lineage of Confucian teachings by drawing on their experience with Buddhist and Daoist learning, naturally had great difficulty in resisting the force of this kind of reasoning. Thus the theory that human nature is good was deeply imprinted on the Song Confucian renaissance from its very beginning. With the passage of time, moreover, the idea of a good human nature became even more entrenched. Because Mencius was the early Confucian most known for advocating the theory of human nature as good, and the slightly later camp of Xunzi and his followers unequivocally rejected the Mencian theory of human nature, mainstream Song Confucians expressly adopted the position of esteeming Mencius and condemning Xunzi in their broader promotion of the theory of the goodness of human nature. To express the logic of this Confucian theory of human nature being good in a single sentence: If human nature is not good, then how are instruction, learning, and self-cultivation possible?

This event is the origin of the traditional Confucian division between Mencius and Xunzi. Behind it lies a paradox. If human nature is good, what is the need for instruction and learning? If human nature is not good, how are instruction, learning, and self-cultivation possible? This enigma can be said to have perplexed Confucians for more than two millennia. ${ }^{3}$ Consciously or not, they are guided and motivated by associated lines of thought. This research can generally be categorized into four types.

2 Ding Fubao 丁福保, annot., Chen Bing 陳兵, comm., Ha Lei 哈否, coll.,'Liuzu dashi fabaotan jing: Xing you di yi 六祖大師法寶壇經. 行由第一 [Platform Sutra of the Sixth Patriarch: Chapter One: Personal History]," in Tan jing 壇經 [Platform Sutra], (Shanghai: Shanghai guji chubanshe, 2011), 22.

3 See Zou Xiaodong 鄒曉東, Xing shan yu zhi jiao 性善與治教 [The Goodness of Human Nature and Governmental Education] (Shanghai: Huadong shifan daxue chubanshe, 2020), 5 . 
The first is the neo-Confucianism in Hong Kong and Taiwan, represented by Mou Zongsan 牟宗三 [1909-1995]. This group carries forward the tradition of seeing human nature as good. Drawing on Immanuel Kant's [1724-1804] concept of autonomy in explicating the Mencian theory of human nature as good, Mou even advocates that humans possess the "intellectual intuition" that Kant denied. He uses this to fill out the epistemological dimensions of his view, which is permeated by the theory that human nature is good. At the same time, Mou draws sharp lines within Song-Ming Confucianism with respect to orthodox and heterodox thinkers, striving to show that Zhu Xi 朱喜 [1130-1200] and the Great Learning [Da xue 大學] lamentably promote thinking along Xunzian lines and thus heteronomy, rather than autonomy. Whereas Mou's research in this area achieves exquisite heights within its established framework, the abolition of the imperial examination system and imperial order in the early twentieth century, especially the New Culture Movement, overturned the Confucian orthodoxy that had held sway since Song and Ming times. Because the work of Mou and his followers adheres closely to the neoConfucian allegiance to Mencius, it became viewed within the academic discourse of modern China's humanities as a study of orthodoxy and heresy or as conservative and apologetic. This can be viewed as a continuation and deepening of neo-Confucianism's elevation of Mencius and condemnation of Xunzi.

Second, slightly after Mou Zongsan, a wave of fervent endorsement of Xunzi arose among scholars of Confucian philosophy throughout the mainland of China. That wave continues to this day. In reaction to the elevation of Mencius and condemnation of Xunzi in neo-Confucianism, these scholars strive to clean up Xunzi's image as an advocate of the theory that human nature is bad. One of these scholars, Liu Youming 劉又銘, argues that Xunzi in fact held “an alternative non-Mencian view of the goodness of human nature, which thus can be called a quasi-view of human nature as good, or a theory of human nature as tending toward goodness."4 Zhou Chicheng 周熾成 [1961-2017] has often argued, "Xunzi's is a theory of human nature as a blank slate [pu 樸], not of human nature as bad." 5 Zhou argues that, otherwise, there is no way to

4 Liu Youming 劉又銘, “Dangdai ruxue de jiben linian 當代儒學的基本理念 [The Foundational Ideas of Contemporary Confucianism]," in Ru lin 儒林 [Confucian Literati], ed. Pang $\mathrm{Pu}$ 龐樸 (Jinan: Shandong daxue chubanshe, 2008), vol. 4; also in Liu Youming, Yige dangdaide, dazhongde Ruxue: Dangdai xin Ruxue lungang 一個當代的、大眾的儒學——當 代新儒學論綱 [A Contemporary Public Confucianism: An Outline of Contemporary New Confucianism] (Beijing: Zhongguo renmin daxue chubanshe, 2019), 42-65.

5 I.e., Zhou Chicheng 周熾成, “Xunzi: Xing pu lun zhe, fei xing e lun zhe 荷子: 性樸論者, 非 性惡論者 [Xunzi: Advocate of Human Nature as a Blank Slate, Not of Human Nature as Bad]," Guangming ribao 光明日報, March 20, 2007. 
answer the fundamental question: "Since human nature is bad, where does goodness come from?" ${ }^{6}$ Liang Tao 梁濤 believes that a full and accurate description of Xunzi's theory of human nature requires seeing human nature as bad but the heart-mind [xin 心] as good. ${ }^{7}$ These studies defend Xunzi and dismiss preconceptions of a partition between Mencius and Xunzi. At the same time, to a very significant extent, they explicate the Xunzi in a highly Mencian way. In other words, pressure from the Mencian view that human nature is good, which demands an answer as to how instruction, learning, and self-cultivation can be possible if human nature is not good, is the basic motivation for these Xunzian scholars' revisionary accounts. We can say that, to a significant extent, these revisionary accounts pay the price of avoiding and minimizing a distinctive divergence between the Xunzi and the Mencius that has been generally affirmed throughout history. This way of redeeming the reputation of Xunzi's theory, even if it succeeds to a certain extent, ultimately has a hard time avoiding a situation in which Xunzi is merely an appendix to Mencius.

Third, "political Confucianism" has thrived in the mainland of China since the twenty-first century began. Ordinarily speaking, the rise of political Confucianism should help draw increased scholarly attention to Xunzi's idea of governmental education by cultivated leaders [junshi zhi jiao 君師 治教]. The force and significance of Xunzi's theory that human nature is bad, as an explanation for why instruction and learning are necessary, might be ripe for a fundamental reappraisal. However, as some scholars point out, the fact that traditional Chinese culture lacks engrained notions of sin and salvation has inhibited further development of Xunzian theory. At present, mainland Chinese "political Confucian" scholars' excavation of the theoretical potential of Xunzi's theory on human nature lags far behind that of the "southof-the-Charles-River" faction of Boston Confucianism, with its background in Christian theology. The representatives of this group, Robert Cummings Neville and John Berthrong, ${ }^{8}$ attempt to connect the Christian doctrine of original sin with Xunzi's theory of human nature. At the same time, they also seek to

6 Zhou Chicheng, “Ni xing yu shun xing: Xunzi renxing lun de neizai jinzhang 逆性與順 性——荀子人性論的內在緊張 [Contravening and Following Human Nature: The Internal Tension of Xunzi's Theory of Human Nature]," Kongziyanjiu 孔子研究, no. 1 (2003).

7 Liang Tao 梁濤, “Xunzi renxing lun bianzheng: Lun Xunzi de xing e, xin shan shuo 荀子 人性論辨正——論荀子的性惡、心善說 [Correcting Xunzi's Theory of Human Nature: On Xunzi's Teaching of Human Nature Being Bad and the Heart-Mind Being Good]," Zhexue yanjiu 哲學研究, no. 5 (2015).

8 Editor's note: Both are affiliated with the Boston University School of Theology. Robert Cummings Neville retired as dean in 2018, and John Berthrong is an associate professor of comparative theology. 
draw on Xunzi and Confucianism's ritual code of ethics in addressing questions surrounding Christian original sin. ${ }^{9}$ Regardless of whether the integration of Christianity and Confucianism conceived of in Neville and Berthrong's Boston Confucianism is ultimately stable, it at least helps inspire non-Christian Confucian scholars to recognize the differences in characteristic teachings between Xunzi and Mencius more fully and to appraise the vast potential of Xunzian arguments more positively.

Fourth, a few scholars have a passion for innovative theory leads them to seek unification of the thought of Mencius and Xunzi despite their twothousand-year-old rivalry. In recent years, Liang Tao at Renmin University has explicitly advocated the integration of the thought of Mencius and Xunzi. In fact, as early as the 1990s, Guo Yi 郭沂 distinguished the characteristic theories of Mencius and Xunzi and labeled them theories of the internal and the external, which means that they are not so much contradictory as different sides of the same coin. Under the label of "moral process theory" [daode guocheng lun 道德過程論], he proposed integrating these internal and external theories..$^{10}$ More recently, Liang Tao has argued that human activities can be divided into a "moral realm" and a "political realm," with the Mencius emphasizing the former and the Xunzi focusing on the latter. In this way, the idea of "integrating Mencius and Xunzi" combines the moral and political realms into a comprehensive arena of human life. ${ }^{11}$ Additionally, through revisionary analysis and arrangement of the concepts of "heaven," "human nature," "emotions [qing 情]," and the "heart-mind," Liu Yuedi 劉悅笛 has attempted to merge

9 See Cai Degui 蔡德貴, “Shi lun Meiguo de Rujia xuepai 試論美國儒家學派 [Preliminary Discussion of the Schools of American Confucianism]," Dangdai ruxue 當代儒學, no. 2 (2015), 207; see also Robert Neville, Boston Confucianism (Albany: State University of New York Press, 2000).

10 See Guo Yi 郭沂, "Daxue xin lun: Jian ping Xin Rujia de youguan lunshu《大學》 新論——兼評新儒家的有關論述 [A New Theory of the Great Learning: With Comments on Related Teachings of New Confucianism]," in Xin Rujia pinglun 新儒家 評論 [Appraisal of New Confucianism], ed. Zheng Jiadong 鄭家棟 and Ye Haiyan 葉海 煙 (Beijing: Zhongguo guangbo dianshi chubanshe, 1995), vol. 2; Guo Yi, "Daxue de sixiang 《大學》的思想 [The Thought of the Great Learning]," in Zhongguo sixiang xueshuo shi, xian-Qin juan 中國思想學說史 - 先秦卷 [History of Theories of Chinese Thought, pre-Qin volume], ed. Zhang Qizhi 張廣之 (Guilin: Guangxi shifan daxue chubanshi, 2007), 1: 276.

11 Liang Tao, “Tonghe Meng Xun, chuangxin ruxue 統合孟荀 創新儒學 [Integrating Mencius and Xunzi, Innovating on Confucian Teachings]," in Zongjiao yu zhexue 宗教 與哲學 (第七輯) [Religion and Philosophy, vol. 7], ed. Zhao Guangming 趙廣明 (Beijing: Sheke wenxian chubanshe, 2018), vol. 7 . 
the characteristic arguments of Mencius and Xunzi. ${ }^{12}$ These four branches of research are particularly self-aware in their advocacy of "integrating Mencius and Xunzi."

To better accomplish this task, researchers must continue to push in the following three directions. First, we must analyze the arguments of Mencius and Xunzi, correctly locating their substantive divergence and fully illuminating shortcomings in their theories. Second, we must thoroughly sort through the more than two millennia-long history of the relationship between Mencius and Xunzi, which involves textual explication of the Mencius and Xunzi, the differences in their epistemology, and ideas about how Mencius and Xunzi might be integrated. In this way, further work on this integration can stand more fully on the shoulders of our predecessors. Third, based on these two types of work, we must integrate Mencius and Xunzi in theoretically innovative ways.

The articles in this issue of $\mathrm{JOCH}$ closely conform to these suggestions. The articles collected here are all highly readable, so I will not bother to outline their content individually.

Last, let me add that a wave of discussion has recently arisen on the relationship between Mencius and Xunzi set off by Li Zehou's 李澤厚 2017 article "Advancing the Thought of Xunzi under the Banner of Mencius: A Defense of My Ethics." ${ }^{13}$ Following its publication, Yang Zebo 楊澤波 quickly published an article in response, "Still Just One Side of Things: On Li Zehou's New Line of Argument."14 In October of that year, Liang Tao collaborated with Tu Weiming 杜維明 in organizing a conference on "Integrating Mencius and Xunzi and Reappraising Confucian Tradition [Tonghe Meng Xun yu daotong chonggu 統合孟荀與道統重估]” at Renmin University, elevating the relationship between Mencius and Xunzi to a matter of reevaluating and restructuring the basic framework of Confucian learning. It is in this context that the Chinese edition of this journal (Journal of Literature, History, and Philosophy [Wen shi

12 Liu Yuedi 劉悅笛, “Meng Xun 'tian-xing-qing—xin' tonghe lun: Cong 'xin tong qing xing’ xin shijiao jiantiao Meng Xun 孟荀‘天-性-情-心’統合論——從心心統情 性,新視角兼祧孟荀 [A Theory Integrating Mencius and Xunzi on 'Heaven-Human Nature-Qing-Mind': A New Perspective Inheriting Mencius and Xunzi through 'the Mind Unifying and Governing Qing and Human Nature'], Wen shizhe 文史哲 [Journal of Literature, History, and Philosophy], no. 2 (2020).

13 Li Zehou 李澤厚, “Ju Meng qi, xing Xun xue: Wei Lunlixue gangyao yi bian 舉孟旗 行荀學——為《倫理學綱要》一讋 [Advancing the Thought of Xunzi under the Banner of Mencius: A Defense of The Essentials of Ethics]," Tansuo yu zhengming 探索與 爭鳴, no. 4 (2017).

14 Yang Zebo 楊澤波, “Reng shi yi pian: Lun Li Zehou de xin pangchu shuo 仍是一偏: 論李 澤厚的新旁出說 [Still Just One Side of Things: On Li Zehou's New Line of Argument]," Tansuo yu zhengming, no. 7 (2017). 
zhe 文史哲]) published its discussion on "The Debate between Mencius and Xunzi and Their Integration" (2020, no. 2). While we have been preparing for the release of this issue on "Reevaluating the Traditional Confucian Division between Mencius and Xunzi," Tu and Liang have been busy at Qilu Press preparing their edited volume Integrating Mencius and Xunzi and Innovating on Confucian Teachings [Tonghe Meng Xun yu chuangxin ruxue 統合孟荀與創新 儒學]. We extend special thanks to Tu and Liang for their support in the process of preparing this publication.

\section{Translated by R.A. Carleo III}

\section{Works Cited}

Cai Degui 蔡德貴. “Shi lun Meiguo de rujia xuepai 試論美國儒家學派 [Preliminary Discussion of the Schools of American Confucianism]." Dangdai ruxue 當代儒學, no. 2 (2015): 205-19.

Ding Fubao 丁福保, annot:; Chen Bing 陳兵, comm; Ha Lei 哈否, coll. “Liuzu dashi fabaotan jing: Xing you di yi 六祖大師法寶壇经 - 行由第一 [Platform Sutra of the Sixth Patriarch: Chapter One: Personal History]." In Tan jing 壇經 [Platform Sutra], 3-37. Shanghai: Shanghai guji chubanshe, 2011.

Dong Zhongshu 董仲舒. “Shi xing 實性 [The Actuality of Human Nature].” In Chunqiu fanlu yizheng 春秋繁露義證 [The Correct Meaning of the Luxuriant Dew of the Spring and Autumn Annals], annot. Su Yu 苏與, ed. Zhong Zhe 鐘哲, 310-12. Beijing: Zhonghua shuyu, 1992.

Guo Yi 郭沂. “Daxue xin lun:Jian ping Xin Rujia de youguan lunshu 《大學》新論—— 兼評新儒家的有關論述 [A New Theory of the Great Learning: With Comments on Related Teachings of New Confucianism]." In Xin Rujia pinglun 新儒家評論 [Appraisal of New Confucianism], edited by Zheng Jiadong 鄭家棟 and Ye Haiyan 葉海煙, 2: 128-57. Beijing: Zhongguo guangbo dianshi chubanshe, 1995.

Guo Yi 郭沂. “Daxue de sixiang 《大學》的思想 [The thought of the Great Learning]." In Zhongguo sixiang xueshuo shi, xian-Qin juan 中國思想學說史 - 先秦卷 [History of Theories of Chinese Thought, Pre-Qin volume], edited by Zhang Qizhi 張豈之, 1: 263-76. Guilin: Guangxi shifan daxue chubanshi, 2007.

Li Zehou 李澤厚. “Ju Meng qi, xing Xun xue: Wei Lunlixue gangyao yi bian 舉孟旗 行荀 學——為《倫理學綱要》一辯 [Advancing the Thought of Xunzi under the Banner of Mencius: A Defense of The Essentials of Ethics]." Tansuo yu zhengming 探索與 爭鳴, no. 4 (2017): 58-62.

Liang Tao 梁濤. “Xunzi renxing lun bianzheng: Lun Xunzi de xing e, xin shan shuo 菌 子人性論辨正一一論荀子的性惡、心善說 [Correcting Xunzi's Theory of Human 
Nature: On Xunzi's Teaching of Human Nature Being Bad and the Heart-Mind Being Good]." Zhexue yanjiu 哲學研究, no. 5 (2015): 71-80.

Liang Tao 梁濤. “Tonghe Meng Xun, chuangxin Ruxue 統合孟荷 創新儒學 [Integrating Mencius and Xunzi, Innovating on Confucian Teachings].” In Zongjiao yu zhexue 宗教與哲學 (第七輯) [Religion and Philosophy, vol. 7], edited by Zhao Guangming 趙廣明, 7: 75-84. Beijing: Sheke wenxian chubanshe, 2018.

Liu Youming 劉又銘. “Dangdai Ruxue de jiben linian 當代儒學的基本理念 [The Foundational Ideas of Contemporary Confucianism]." In Ru lin 儒林 [Confucian Literati], edited by Pang Pu 龐樸, vol. 4. Jinan: Shandong daxue chubanshe, 2008.

Liu Youming 劉又銘. Yige dangdaide, dazhongde Ruxue: Dangdai xin Ruxue lungang 一個當代的、大眾的儒學——當代新儒學論綱 [A Contemporary Public Confucianism: An Outline of Contemporary New Confucianism]. Beijing: Zhongguo renmin daxue chubanshe, 2019.

Liu Yuedi 劉悅笛. “Meng Xun 'tian—xing—qing—xin' tonghe lun: Cong 'xin tong qing xing’ xin shijiao jiantiao Meng Xun 孟荀 ‘天 - 性 - 情 - 心’ 統合論——從 ‘心統 情性” 新視角兼祧孟荀 [A Theory Integrating Mencius and Xunzi on 'HeavenHuman Nature-Qing-Mind': A New Perspective Inheriting Mencius and Xunzi through 'the Mind Unifying and Governing Qing and Human Nature']." Wen shi zhe 文史哲, no. 2 (2020): 109-12.

Neville, Robert. Boston Confucianism. Albany: State University of New York Press, 2000. Yang Zebo 楊澤波. “Reng shi yi pian: Lun Li Zehou de xin pangchu shuo 仍是一偏: 論李澤厚的新旁出說 [Still Just One Side of Things: On Li Zehou's New Line of Argument]." Tansuo yu zhengming 探索與爭鳴, no. 7 (2017): 6o-66.

Zhou Chicheng 周熾成. “Ni xing yu shun xing: Xunzi renxing lun de neizai jinzhang 逆性與順性: 荀子人性論的內在緊張 [Contravening and Following Human Nature: The Internal Tension of Xunzi's Theory of Human Nature]." Kongzi yanjiu 孔子研究, no. 1 (2003): 56-62.

Zhou Chicheng 周熾成. “Xunzi: Xing pu lun zhe, fei xing e lun zhe 荷子: 性樸論者, 非性惡論者 [Xunzi: Advocate of Human Nature as a Blank Slate, Not of Human Nature as Bad]." Guangming ribao 光明日報, March 20, 2007, 11.

Zou Xiaodong 鄒曉東. Xing shan yu zhi jiao 性善與治教 [The Goodness of Human Nature and Governmental]. Shanghai: Huadong shifan daxue chubanshe, 2020. 